\title{
Weldability and Lamellar Tearing Susceptibility of High-Strength SN 490C Steel Plates
}

\author{
Donghyun Van ${ }^{1}$, Seung Hwan Lee ${ }^{1} * \mathbb{D}$, Kihyuk Kim ${ }^{2}$ and Hoseop Sim ${ }^{2}$ \\ 1 School of Aerospace and Mechanical Engineering, Korea Aerospace University, 76 Hanggongdaehang-ro, \\ Deokyang-gu, Goyang-si 10540, Korea; bandh@daum.net \\ 2 A Plate Research Team of Dongkuk Steel R\&D Center, 70 Geonposaneop-ro 3214 beon-gil, Daesong-myun, \\ Nam-gu, Pohang 37874, Korea; kihyuk.kim@dongkuk.com (K.K.); hoseop.sim@dongkuk.com (H.S.) \\ * Correspondence: seunglee@kau.ac.kr; Tel.: +82-2-300-0106
}

Received: 16 April 2019; Accepted: 9 May 2019; Published: 11 May 2019

\begin{abstract}
In this study, weldability and cracking susceptibility of SN 490C steel were firstly investigated. For this study, SN 490C thick plates which had been developed for anti-seismic steel of building structures were welded by flux-cored arc welding (FCAW) and submerged arc welding (SAW) processes based on welding conditions of actual construction site. Weldments using the plates with different thickness were produced using E71T-1C and EH14 filler wires, respectively. For the weldability tests, various welded joints such as butt and T-joints were examined. After welding, microstructure analysis was performed. Various microstructures were found depending on the location of the weldments. Heat effects by multi-pass welding were correlated with the microstructure. The microstructure was correlated with the hardness profile and the impact test result. In addition, the through-thickness tensile test, window test, and Cranfield test were conducted to evaluate sensitivity of lamellar tearing, which may occur during tensile restraint stress of welds. As a result of the tests, it was found that the $\mathrm{SN} 490 \mathrm{C}$ steel was sufficiently resistant to lamellar tearing.
\end{abstract}

Keywords: anti-seismic steel; SN 490C; weldability; lamellar tear; window test; Cranfield test

\section{Introduction}

Concerns about the safety of buildings and steel structures are growing due to the occurrence of severe earthquakes and typhoons worldwide, including Mexico, Indonesia, Italy, Chile, Japan, and China. Many studies have been done to minimize damages caused by these disasters. In particular, a study on the 1994 Northridge earthquake in the USA, the 1995 Kobe earthquake in Japan, and the 2008 Sichuan earthquake in China found that steel structures suffered relatively minor damage compared to other structural materials such as concrete [1]. After years of continuous research, researchers have confirmed that the properties of steel structures used in buildings are important factors that affect the safety of structures in case of an earthquake. For these reasons, the seismic design and safety standards regarding earthquakes are being reinforced by mandatory application of anti-seismic steel in areas where earthquakes are likely [2-5]. Safety standards for building structures are being reinforced by these social demands.

In order to meet the enhanced standards or code for anti-seismic performance, it is necessary to develop and apply high-strength steels for building structures unlike typical carbon steel. In the 1980s, high-strength structural steel for anti-seismic performance started to be developed due to frequent earthquakes in Japan. Rolled steels for building structures, which is named "SN", have been developed to meet the higher safety standards for seismic resistance. The high-strength structural steel requires higher quality than normal steel from the viewpoint of mechanical properties. In order to satisfy the high quality level, high-strength steels for building structures are manufactured through special 
technologies such as alloy composition adjustment and controlled rolling [6]. Moreover, it is necessary to thoroughly examine weldability of the developed steel because the main steel structure used in building construction is manufactured through welding of the steels $[7,8]$. The high-strength rolled steels for building structures require more strict limitations than general steels, in relation to the yield strength, the upper/lower limits of the tensile strength, and the yield ratio $[9,10]$.

Specifically, the high-strength rolled steel for building structures should be constructed to control the range of yield strength. The steel also has a low yield ratio ( 0.8 or less) for the improvement of seismic performance. The yield ratio is the ratio of the yield strength to the tensile strength of the steel. The reason for the yield ratio below a certain level is to maximize margin of time from the start of plastic deformation of the steel to the final fracture. Therefore, the energy of the earthquake can be absorbed into the building to minimize human casualties [11].

In addition to the properties of the steel mentioned above, weldability is an important property required for enhanced seismic performance [10]. Weldability refers to the degree of capability which satisfies its performance depending on its purpose, when the welded part is manufactured with a specific welding method and material. Various tests are used to evaluate the weldability of the welded steel structures. Carbon equivalent (CE) and weld cracking parameter ( $\mathrm{Pcm}$ ) were also used to estimate the weldability. CE is an index which combines the effects of different alloying elements used in carbon steels with an equivalent amount of carbon [12]. Pcm is an index that predicts the weld crack susceptibility [13].

Weldability tests focus mainly on the evaluation of the metallurgical or mechanical properties of the weldment. The test methods to evaluate metallurgical properties in the welded part include chemical component analysis and macro- and micro-examination. The methods to evaluate the mechanical properties of the welded part are tensile test, bending test, hardness test, and toughness test.

One of the most important considerations related to weldability is the crack that may occur in the weldment. In order to satisfy the mechanical properties, the weldments should prevent various cracks that may occur during the manufacturing process. Cracks can seriously degrade the mechanical properties of weldments and can have a detrimental effect on the stability of structures. For this reason, all weldments are required to have crack resistance. In particular, there have been many cases where structures were destroyed due to the formation and progress of lamellar tearing [14]. In the case of weldments, where strong tensile stress is formed perpendicular to the surface of the base material in T-joints and fillet joints, cascade-shaped lamellar tearing is created parallel to the surface of the base material in the heat affected zone (HAZ) and its adjacent zones. The lamellar tearing is known to be caused by lack of ductility in the through-thickness direction [15]. There are various tests to evaluate the weldability related to cracking. The tests for lamellar tearing susceptibility are through-thickness tensile test [16], window test [17], and Cranfield test [18].

Sakino et al. [19] conducted a study on the weldability of SN 400B and SN 490B. Thermo-effects, mechanical properties, and the microstructure of manufactured weldments were analyzed. In addition, Sakino and Kim [20] manufactured single-layer and multi-layer weldments with SN 400 steel and studied the impact toughness depending on welding conditions. In the case of the multi-layer welding, the Charpy absorbed energy increased compared to the single-pass welding in both high-toughness steel and low-toughness steel. Furuya et al. [21] utilized the gas metal arc welding (GMAW) process with SN 400 and SN 490 steel to produce single-layer and multi-layer welds. Weldability was evaluated by microstructure analysis, hardness test, and impact toughness test on the weldments. Qui et al. [15] investigated the effects of the welding thermal cycle and cold working on the ductility of SN 490 steel. Using a simulation technique of the welding thermal cycle, they claimed that the deterioration of ductility in SN490 by welding heat input is caused by the precipitation of a great deal of carbides, and the effect of cold working only relates to the void growth and void coalescence in SN490. Hasebe et al. [22] conducted tests on various steels to evaluate the susceptibility of lamellar tearing. The through-thickness properties of the carbon steels were investigated. The results show that the susceptibility to lamellar tearing of the plates can be arranged successfully by through-thickness 
ductility and the content of sulfur in the steels. Miura [23] carried out tensile tests at high temperatures ranging from 450 to $650^{\circ} \mathrm{C}$ using SN 400B and SN490B steel plates. They suggested an approximation equation, which can predict yield and tensile strengths in this temperature range. Tenderan et al. [24] evaluated anti-seismic performance using the steel moment-resisting frames (SMRFs) manufactured from SN 490B steels. They generated a thumb rule for ductile fractures which can be generated during an earthquake. Kayamori et al. [25] modified the crack tip opening displacement (CTOD) design curve used for fracture assessment. They considered the yield to tensile ratio into the CTOD design curve for better estimation of a fracture. Choi et al. [26] performed various experiments to estimate thermal properties such as thermal conductivity and specific heat using SN 400 steel plates. They compared the experimental results conducted at room temperature and high temperature.

Even though many studies have been conducted related to cracks, fractures, and thermal properties on the SN series steel, none of those studies evaluated the mechanical properties of rolled steels for building structures, especially weldability and crack resistance to lamellar tearing of SN 490C steel.

In this study, the weldability of an SN 490C plate was comprehensively estimated including lamellar tearing susceptibility for the first time. In order to evaluate weldability of the steel, tensile test, bending test, hardness test, and toughness test were conducted on the welded part manufactured through a flux-cored arc welding (FCAW) process and a submerged arc welding (SAW) process. We investigated the microstructure of the welded part. In addition, crack formation was examined for all of the welds, and additional lamellar tearing susceptibility was evaluated. Through-thickness test, window test, and Cranfield test were conducted to evaluate the lamellar tearing susceptibility.

\section{Experimental Procedures}

SN 490C plates, manufactured by controlled rolling were used in this study. The thicknesses of the plates were 30 and $70 \mathrm{~mm}$, respectively. The FCAW and SAW processes were used to produce the weldment of the SN 490C. In case of the plate with $30 \mathrm{~mm}$ thickness, the type of the weld joint was single bevel grooved butt joint as shown in Figure 1a.

(a)

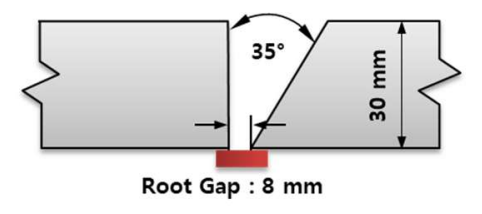

(b)

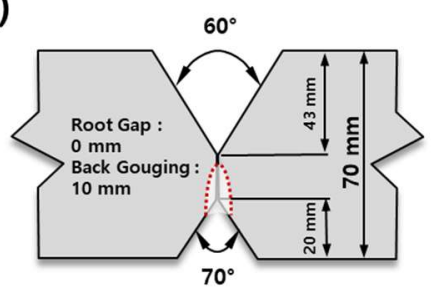

Figure 1. (a) Single beveled groove of the $30 \mathrm{~mm}$ thick plate; (b) double V groove of the $70 \mathrm{~mm}$ thick plate.

The bevel angle was $35^{\circ}$ and the width of the root gap was $8 \mathrm{~mm}$. Welding was performed in the flat position $(1 G)$ with the conditions listed in Table 1.

Table 1. Flux-cored arc welding (FCAW) conditions for the $30 \mathrm{~mm}$ thick plate.

\begin{tabular}{|c|c|c|c|c|c|c|c|c|}
\hline Pass & Process & Polarity & $\begin{array}{l}\text { Wire Size } \\
(\mathrm{mm})\end{array}$ & $\begin{array}{l}\text { Current } \\
\text { (A) }\end{array}$ & $\begin{array}{l}\text { Voltage } \\
\text { (V) }\end{array}$ & $\begin{array}{c}\text { Speed } \\
(\mathrm{cm} / \mathrm{min})\end{array}$ & $\begin{array}{c}\text { Interpass } \\
\text { Temperature }\left({ }^{\circ} \mathrm{C}\right)\end{array}$ & $\begin{array}{c}\text { Heat Input } \\
(\mathrm{kJ} / \mathrm{cm})\end{array}$ \\
\hline 1 & FCAW & DCRP & 1.4 & 420 & 40 & 25 & 36 & 40 \\
\hline 3 & FCAW & DCRP & 1.4 & 420 & 40 & 25 & 88 & 40 \\
\hline 4 & FCAW & DCRP & 1.4 & 420 & 40 & 25 & 126 & 40 \\
\hline 5 & FCAW & DCRP & 1.4 & 420 & 40 & 25 & 130 & 40 \\
\hline 8 & FCAW & DCRP & 1.4 & 420 & 40 & 25 & 113 & 40 \\
\hline
\end{tabular}


A flux cored wire, E71T-1C with a diameter of $1.4 \mathrm{~mm}$, corresponding to AWS A5.20 [27] was used. In the case of the plate with $70 \mathrm{~mm}$ thickness, the type of the weld joint was double $\mathrm{V}$ bevel grooved butt joint as shown in Figure 1b. The bevel angles in the upper and lower grooves were $60^{\circ}$ and $70^{\circ}$, respectively. The width of the root gap was $0 \mathrm{~mm}$. Welding was performed in the flat position (1G) with the conditions shown in Table 2.

Table 2. Submerged arc welding (SAW) conditions for the $70 \mathrm{~mm}$ thick plate.

\begin{tabular}{|c|c|c|c|c|c|c|c|c|}
\hline Pass & Process & Polarity & $\begin{array}{l}\text { Wire Size } \\
(\mathrm{mm})\end{array}$ & $\begin{array}{l}\text { Current } \\
\text { (A) }\end{array}$ & $\begin{array}{l}\text { Voltage } \\
\text { (V) }\end{array}$ & $\begin{array}{c}\text { Speed } \\
(\mathrm{cm} / \mathrm{min})\end{array}$ & $\begin{array}{c}\text { Interpass } \\
\text { Temperature }\left({ }^{\circ} \mathrm{C}\right)\end{array}$ & $\begin{array}{c}\text { Heat Input } \\
(\mathrm{kJ} / \mathrm{cm})\end{array}$ \\
\hline 1 & FCAW & DCRP & 1.2 & 250 & 30 & 32 & 80 & 15 \\
\hline 2 & SAW & $\mathrm{AC}$ & 4.8 & 850 & 38 & 32 & 85 & 60 \\
\hline 3 & SAW & $\mathrm{AC}$ & 4.8 & 850 & 38 & 32 & 96 & 60 \\
\hline 4 & SAW & $\mathrm{AC}$ & 4.8 & 850 & 38 & 32 & 120 & 60 \\
\hline 5 & SAW & $\mathrm{AC}$ & 4.8 & 850 & 38 & 32 & 150 & 60 \\
\hline 6 & SAW & $\mathrm{AC}$ & 4.8 & 850 & 38 & 32 & 120 & 60 \\
\hline 7 & SAW & $\mathrm{AC}$ & 4.8 & 850 & 38 & 32 & 159 & 60 \\
\hline 8 & SAW & $\mathrm{AC}$ & 4.8 & 850 & 38 & 32 & 181 & 60 \\
\hline 9 & SAW & $\mathrm{AC}$ & 4.8 & 850 & 38 & 32 & 123 & 60 \\
\hline 10 & SAW & $\mathrm{AC}$ & 4.8 & 850 & 38 & 32 & 151 & 60 \\
\hline 11 & SAW & $\mathrm{AC}$ & 4.8 & 850 & 38 & 32 & 179 & 60 \\
\hline 12 & SAW & $\mathrm{AC}$ & 4.8 & 850 & 38 & 32 & 140 & 60 \\
\hline 13 & SAW & $\mathrm{AC}$ & 4.8 & 850 & 38 & 32 & 153 & 60 \\
\hline 14 & SAW & $\mathrm{AC}$ & 4.8 & 850 & 38 & 32 & 178 & 60 \\
\hline 15 & SAW & $\mathrm{AC}$ & 4.8 & 850 & 38 & 32 & 196 & 60 \\
\hline 16 & SAW & $\mathrm{AC}$ & 4.8 & 850 & 38 & 32 & 146 & 60 \\
\hline 17 & SAW & $\mathrm{AC}$ & 4.8 & 850 & 38 & 32 & 175 & 60 \\
\hline \multicolumn{9}{|c|}{ Back Gouging } \\
\hline 18 & SAW & $\mathrm{AC}$ & 4.8 & 850 & 38 & 32 & 162 & 60 \\
\hline 19 & SAW & $\mathrm{AC}$ & 4.8 & 850 & 38 & 32 & 198 & 60 \\
\hline 20 & SAW & $\mathrm{AC}$ & 4.8 & 850 & 38 & 32 & 150 & 60 \\
\hline 21 & SAW & $\mathrm{AC}$ & 4.8 & 850 & 38 & 32 & 178 & 60 \\
\hline 22 & SAW & $\mathrm{AC}$ & 4.8 & 850 & 38 & 32 & 192 & 60 \\
\hline 23 & SAW & $\mathrm{AC}$ & 4.8 & 850 & 38 & 32 & 200 & 60 \\
\hline
\end{tabular}

A solid wire, EH14 with a diameter of $4.8 \mathrm{~mm}$, corresponding to AWS A5.17 [28] was used. The chemical composition of the E71T-1C and EH14 wires is listed in Table 3. The $30 \mathrm{~mm}$ thick weldments were manufactured with multi-layer welds of eight passes, and the $70 \mathrm{~mm}$ thick weldments were manufactured with multi-layer welds of 32 passes. Tensile test, bending test, hardness test, and toughness test were carried out for each weld. For the tensile test, uniaxial tensile tests were conducted using a universal testing machine (Z1200 of Zwick Roell company, Ulm, Germany). An extensometer was used for the study. For the bending test, in both $30 \mathrm{~mm}$ thick and $70 \mathrm{~mm}$ thick plates, test samples were machined to the width of $30 \mathrm{~mm}$, the thickness of $30 \mathrm{~mm}$, and length of $250 \mathrm{~mm}$. The specimens were bent by a former with a diameter four times the thickness of the plates using a three-points bending machine.

Table 3. Chemical composition of the filler wires.

\begin{tabular}{ccccccccccc}
\hline \multirow{2}{*}{ Process } & \multirow{2}{*}{ Specification } & C & Mn & P & S & Si & Cr & Ni & Cu & Fe \\
\cline { 3 - 11 } & & & & \multicolumn{7}{c}{ wt. $\%$} \\
FCAW & E71T-1C & 0.03 & 0.08 & 0.013 & 0.005 & 0.10 & 0.56 & 0.02 & 0.45 & Bal. \\
\hline SAW & EH14 & 0.07 & 1.85 & 0.015 & 0.017 & 0.021 & 0.021 & 0.016 & 0.014 & Bal. \\
\hline
\end{tabular}

In addition to the butt joint weldment, T-joint weldments were also tested because the T-joint is often used in building structures. Two types of T-joint weldments were tested to evaluate the weldability of SN 490C. In the first case, a full-penetration weldment was produced in the horizontal (2G) position by an FCAW process. The shape of the weld joint was a single beveled T-joint as shown in Figure 2a. The bevel angle was $35^{\circ}$ and the width of root gap was $7 \mathrm{~mm}$. In the second case, two 
partial-penetration weldments were produced in the horizontal (2F) position by an FCAW process. The shape of the weld joint is the double-fillet T-joint as shown in Figure 2b. In each weldment, macro-examination and hardness tests were conducted.
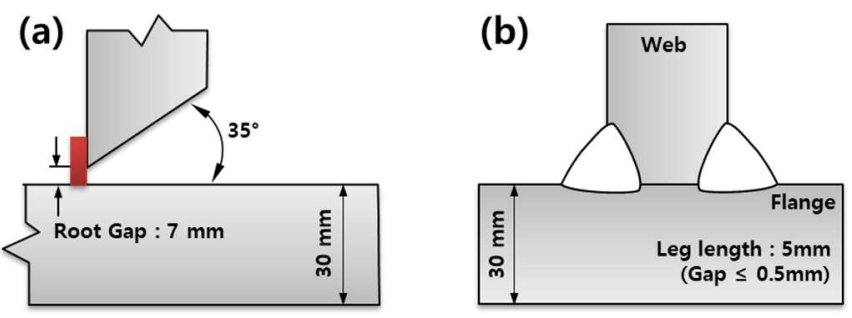

Figure 2. (a) Single beveled T-joint; (b) double-fillet T-joint.

For a tensile test of the weldment, flat-shaped and round-shaped specimens were machined, according to ASTM A370. ASTM A370 includes how to produce the specimens for a tensile test, a guided bend test, and a Charpy V-notch impact test as well. Therefore, in order to conduct guided bend test for this weldment, face and root bend test specimens were produced according to ASTM A370. In addition, specimens of the Charpy V-notch impact test were produced according to ASTM A370. Once the specimens were ready, according to ASTM E8/E8M-13a, ASTM E190, ASTM E23, and ASTM E92, the tensile test, the guided bend test, the toughness test and the hardness test were conducted, respectively. All tests were conducted using the plates of thickness 30 and $70 \mathrm{~mm}$. In this study, Z1200 of the Zwick Roell company was used for the tensile test and the guided bend test. PSW 1000 of the Zwick Roell company was used for the Charpy V-notch impact test. The average of Charpy absorbed energy was obtained as a result of three measurements at $0{ }^{\circ} \mathrm{C}$. In the hardness test, the average of Vickers hardness was calculated as a result of three measurements at room temperature with a load of 0.98 N using a HV-114 (Mitutoyo, Kawasaki, Japan).

Polishing and machining of weldment were performed to observe the microstructure of the weldment [29]. The weldment was then etched with 3\% Nital (3\% nitric acid $+97 \%$ ethanol) etchant. Using a Leica WBS-600AN optical microscope (Leica microsystems, Wetzlar, Germany), the microstructure of the weldment was observed.

Additionally, various tests were carried out to evaluate the lamellar tearing susceptibility of the base metal and the weldment. First, through-thickness tensile tests were conducted according to ASTM A770. Full-penetration welds were manufactured by FCAW and the window test was conducted. Partial-penetration welds were manufactured by FCAW and the Cranfield test was conducted.

\section{Results}

\subsection{Microstructure Analysis}

Table 4 indicates chemical composition, CE, and Pcm depending on thickness and positions of the SN 490C plates. The CE and Pcm of the base metal suggested by the industrial standard vary depending on the thickness. The $30 \mathrm{~mm}$ thick plate has a CE of 0.44 or less and a Pcm of 0.29 or less. The $70 \mathrm{~mm}$ thick plate has a CE of 0.46 or less and a Pcm of 0.29 or less. The base metal used in this study shows that the CE and Pcm satisfy the industry standards for all thicknesses [3].

Before welding, the microstructure of control-rolled steel plate shown in Figure 3 was observed using an optical microscope. Figure 3 shows optical micrographs of a base metal plate with $30 \mathrm{~mm}$ thickness. The pictures were taken with 200 magnifications and 500 magnifications at $t / 4$ and $t / 2$ of plate thickness $(t)$. Similarly, Figure 4 shows pictures taken under the same condition for a base material with a thickness of $70 \mathrm{~mm}$. Optical microscope observation of the base material shows the ferrite and pearlite structure typically found in carbon steel. The elongation of the grain was shown in a rolled direction. The grain size varied approximately from 10 to $50 \mu \mathrm{m}$, and was generally uniform. As a result, there was no difference in the microstructure of the base metals depending on thickness. 
Table 4. Chemical composition, carbon equivalent (CE), and weld cracking parameter (Pcm) depending on thickness and positions of the SN 490C plates.

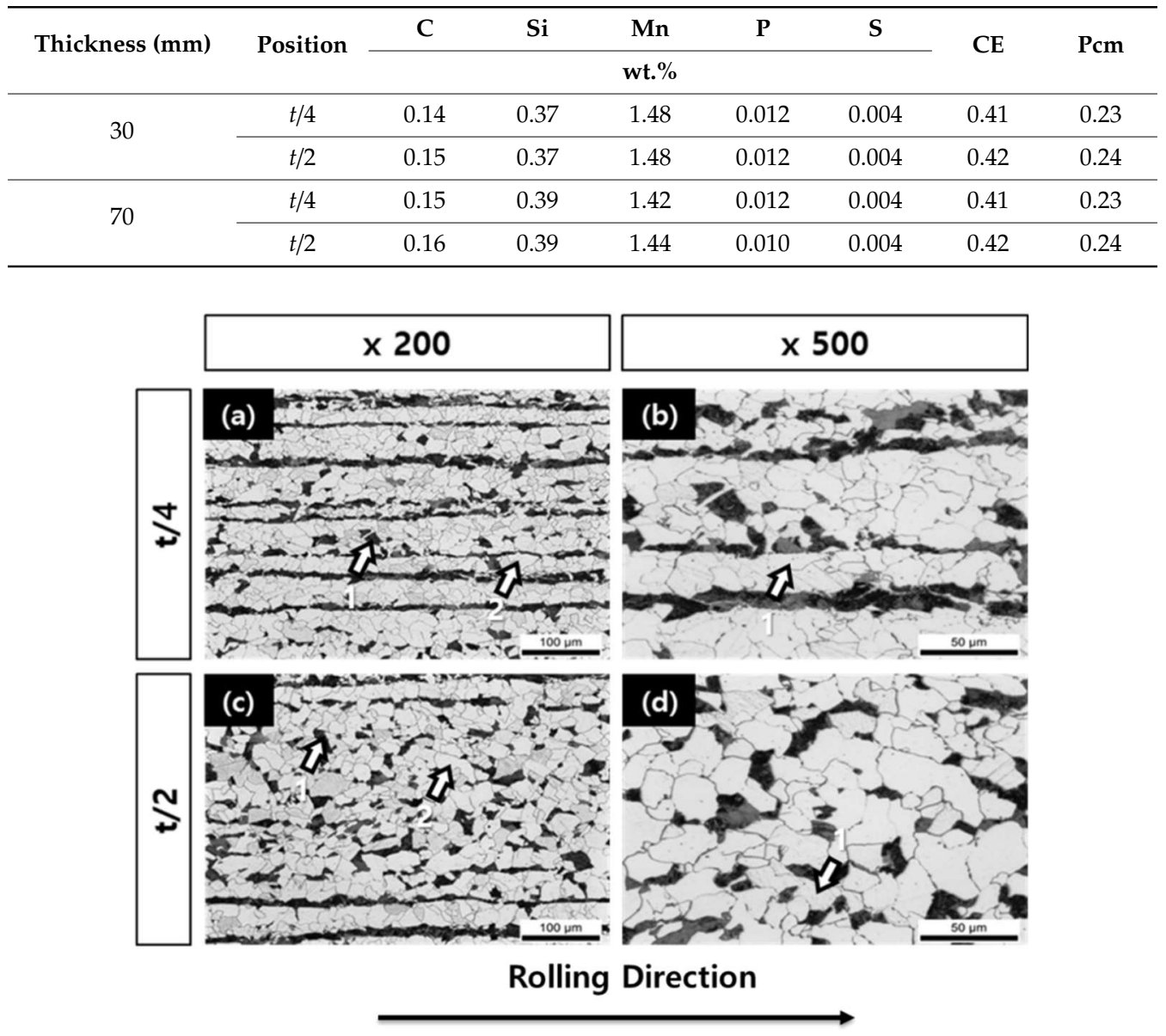

Figure 3. Optical micrographs of the $30 \mathrm{~mm}$ thick plate: (a) 1-pearlite, 2-ferrite; (b) 1-elongation of the grain; (c) 1-pearlite, 2-ferrite; (d) 1-elongation of the grain.

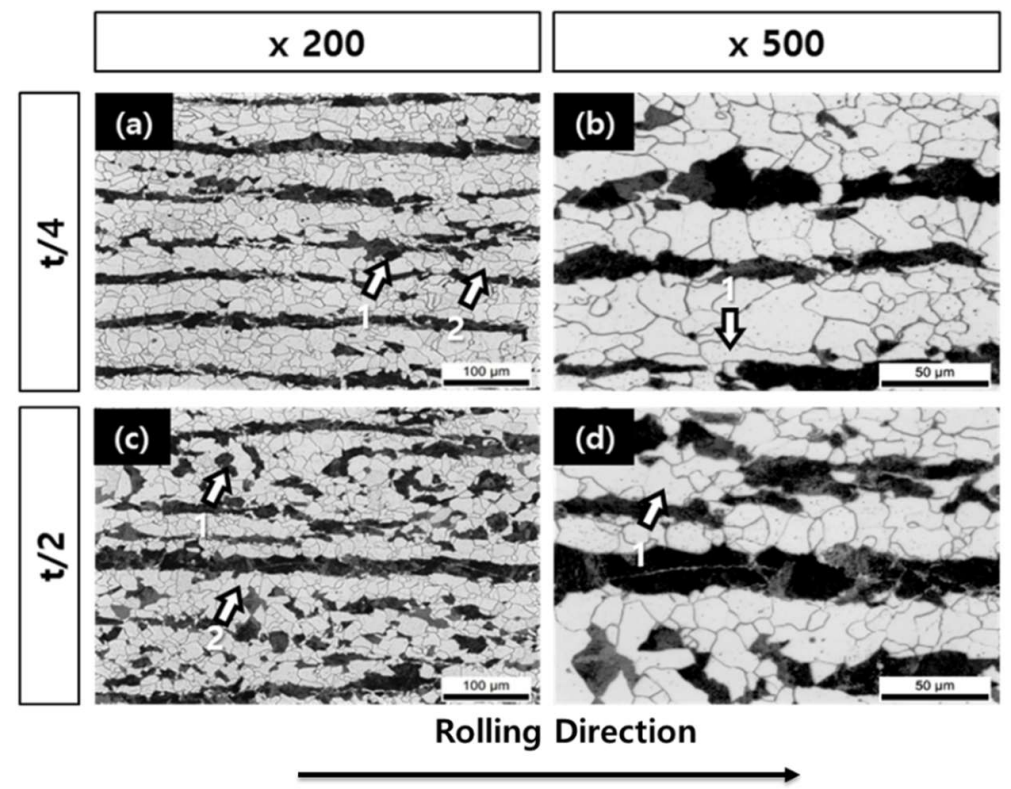

Figure 4. Optical micrographs of the $70 \mathrm{~mm}$ thick plate: (a) 1-pearlite, 2-ferrite; (b) 1-elongation of the grain; (c) 1-pearlite, 2-ferrite; (d) 1-elongation of the grain. 
Figure 5; Figure 6 show the microstructures of the weldment manufactured by the FCAW and SAW processes under the conditions listed in Table 1; Table 2, respectively. The entire weld bead shapes can be found from the inset of Figures $5 \mathrm{a}$ and $6 \mathrm{a}$ in the following two cases: $30 \mathrm{~mm}$ thick plate with eight multi-passes and $70 \mathrm{~mm}$ thick plate with 32 multi-passes. No cracks or defects were observed in Figures 5 and 6. Generally, the microstructure of the weldment comprises the weld metal, the heat affected zone (HAZ), and the base metal. The HAZs are sometimes subdivided into coarse-grained HAZ (CGHAZ) and fine-grained HAZ (FGHAZ). When welding SN 490C, the fine-grained ferrite and pearlite in the base metal are heated above the temperature in which the welding heat partially transforms the original microstructure into the austenite phase. The microstructure of the weld metal produced by the FCAW and SAW processes was partially similar to that of typical arc welding.
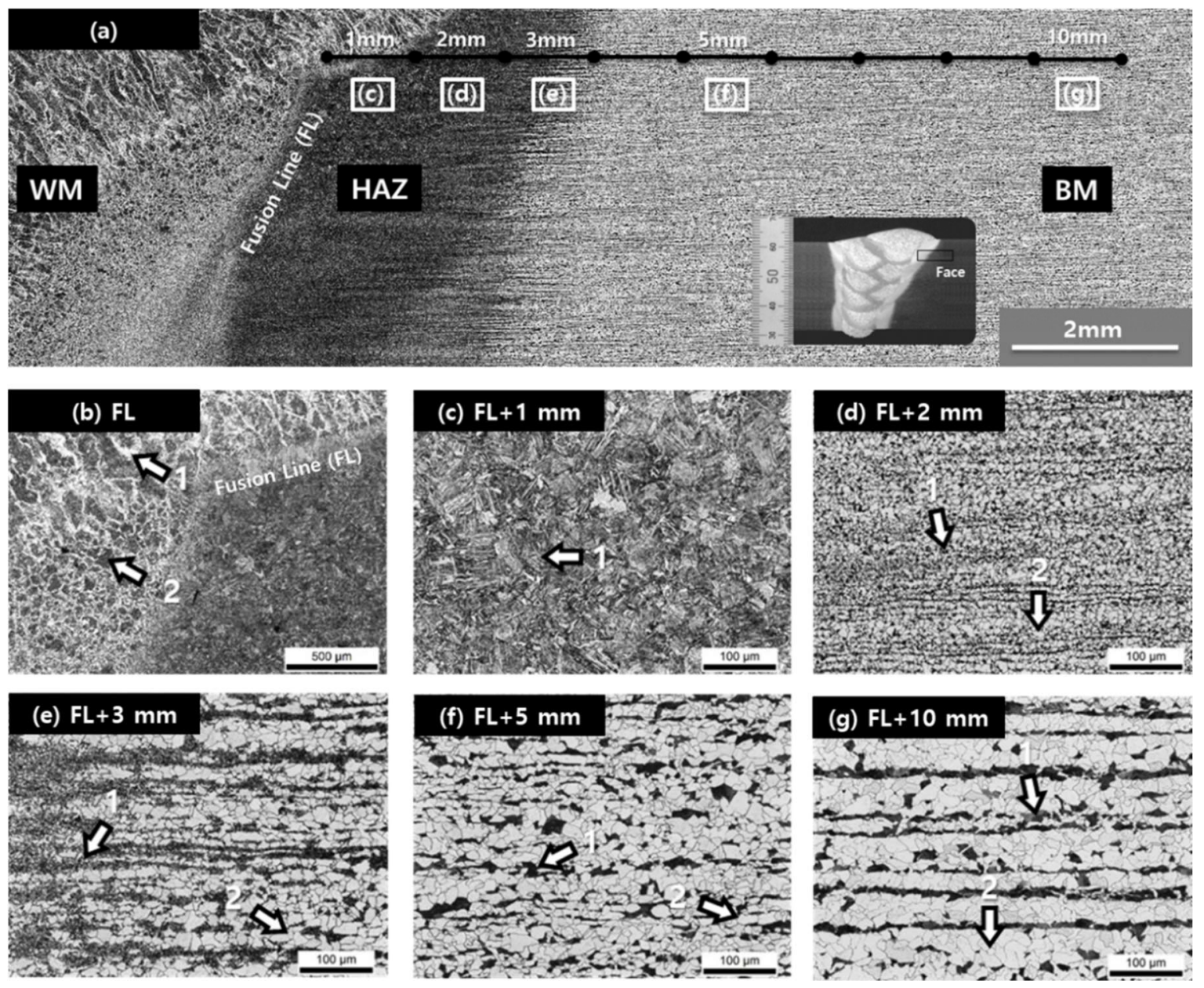

Figure 5. Optical micrographs of the weldment with a butt joint manufactured by FCAW on the $30 \mathrm{~mm}$ thick plate: (a) The weldment; (b) the fusion line: 1-grain boundary ferrite, 2-acicular ferrite; (c) fusion line $+1 \mathrm{~mm}$ : 1-upper bainite; (d) fusion line $+2 \mathrm{~mm}$ : 1-fine pearlite, 2-fine polygonal ferrite; (e) fusion line $+3 \mathrm{~mm}$ : 1-degenerated pearlite, 2-polygonal ferrite; (f) fusion line $+5 \mathrm{~mm}$ : 1 -lamellar pearlite, 2-polygonal ferrite; (g) fusion line $+10 \mathrm{~mm}$ : 1-lamellar pearlite, 2-polygonal ferrite. 

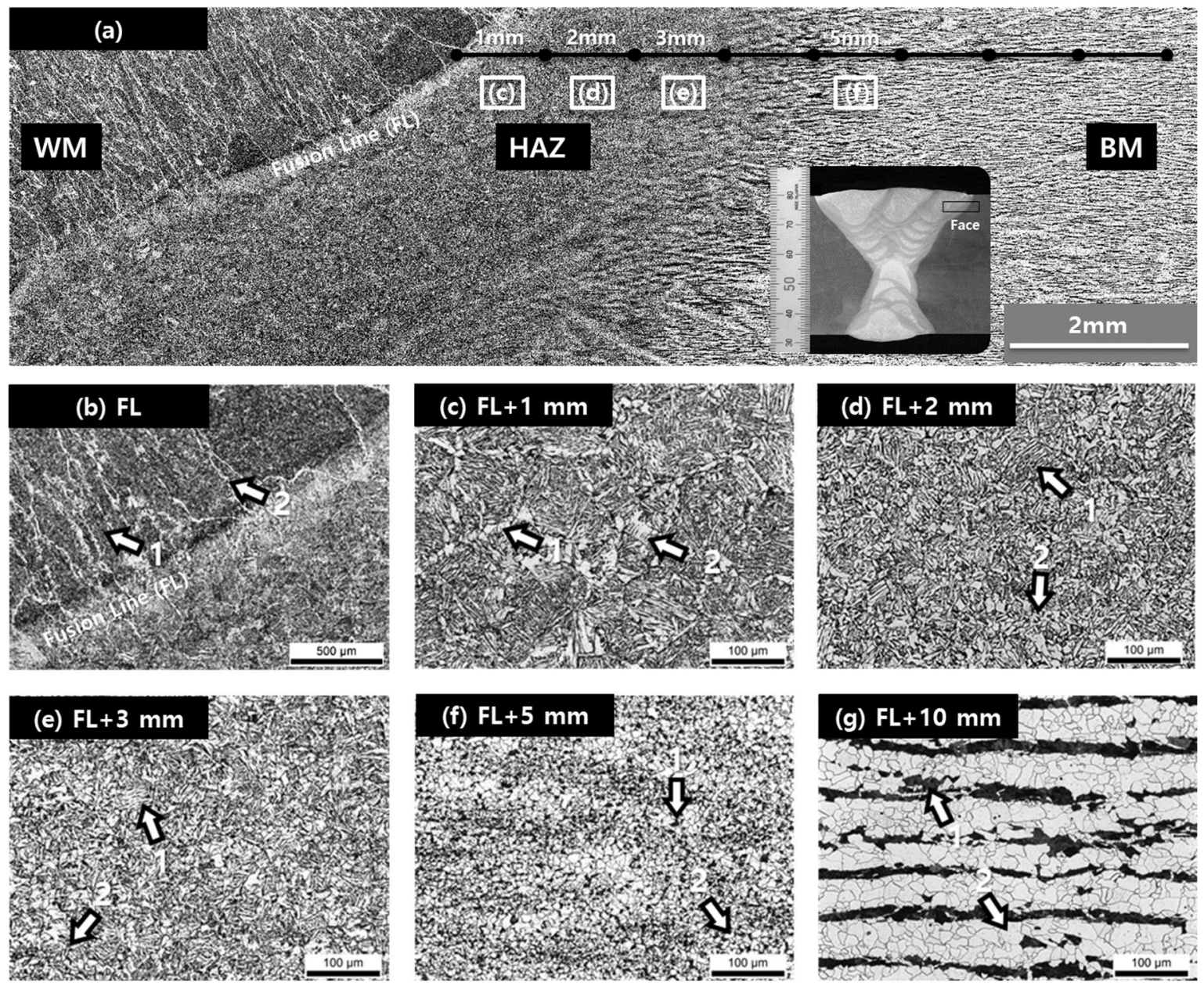

Figure 6. Optical micrographs of the weldment with butt joint manufactured by SAW on the $70 \mathrm{~mm}$ thickness: (a) The weldment; (b) the fusion line: 1-acicular ferrite, 2-grain boundary ferrite; (c) fusion line $+1 \mathrm{~mm}$ : 1 -grain boundary ferrite, 2 -upper bainite; (d) fusion line $+2 \mathrm{~mm}$ : 1 -upper bainite, 2-intragranular ferrite; (e) fusion line $+3 \mathrm{~mm}$ : 1 -upper bainite, 2 -fine pearlite; (f) fusion line +5 $\mathrm{mm}$ : 1-fine lamellar pearlite, 2-fine polygonal ferrite; (g) fusion line $+10 \mathrm{~mm}$ : 1—lamellar pearlite, 2-polygonal ferrite.

The overall microstructure of the weldment in each thickness is depicted in Figures $5 \mathrm{a}$ and $6 \mathrm{a}$. In the weld metal where epitaxial growth occurs, solidification of the grains occurred toward the center of the weldment as shown in Figures 5a and 6a. In the weld metal (WM) shown in Figures $5 b$ and $6 \mathrm{~b}$, the grain boundary ferrite (GBF) structure with white and the acicular ferrite (AF) were mainly found [30]. More AF was found in Figure $6 \mathrm{~b}$ compare with AF in Figure 5b. This is because the EH14 filler wire has more Mn wt.\% than that of the E71T-1C filler wire. This caused the decrease of the GBF in Figure $6 b$ compared to the GBF in Figure $5 b$ [31]. The coarse-grained microstructure usually exists near the fusion line (FL) in the HAZ. As seen in Figures $5 \mathrm{c}$ and $6 \mathrm{c}, \mathrm{d}, \mathrm{e}$, the upper bainite was developed in CGHAZ area. It was observed that the average bainitic packet size became smaller from the FL to the FGHAZ in the CGHAZ produced by SAW. Since the heat input of the SAW process was higher than that of the FCAW process [32], the average bainitic packet size in Figure $6 \mathrm{c}$ is about $200 \mu \mathrm{m}$, which is bigger than the size of $100 \mu \mathrm{m}$ seen in Figure 5c. In the case of the control-rolled steel, it is known that the martensite/austenite constituent (MA) is generated due to the welding heat depending on the amount of carbon in the steel when the upper bainite structure is formed [33-35]. Therefore, in the CGHAZ, the hardness was expected to increase due to the existence of the upper bainite. The area of the CGHAZ produced by SAW was wider than that of the weldment produced by FCAW due to the 
amount of the heat input. Meanwhile, in the FGHAZ, the ferrite-pearlite structure of the grain which is finer than that of the base material is observed, as shown in Figures $5 \mathrm{~d}$ and 6e,f. Specially, in Figure 5, the amount of the polygonal ferrite became larger from the fusion line to the base metal. The finer structure can be explained by the repetitive heat input of the multi-pass welding [36]. Therefore, it is expected that the FGHAZ will improve the mechanical properties such as toughness.

\subsection{Mechanical Properties}

The tensile test results depending on thickness and position of the SN 490C plates formed by controlled rolling are shown in Table 5 . In the case of the $30 \mathrm{~mm}$ thick plate, the tensile tests in the transverse direction showed that the tensile strength was $546 \mathrm{MPa}$ and the yield ratio was $71 \%$. In the case of the $70 \mathrm{~mm}$ thick plate, the tensile strength was $526 \mathrm{MPa}$ and the yield ratio was $73 \%$.

Table 5. Tensile test results depending on thickness and position of the SN 490C plates.

\begin{tabular}{|c|c|c|c|c|c|c|}
\hline $\begin{array}{l}\text { Thickness } \\
\text { (mm) }\end{array}$ & Direction & Position & $\begin{array}{l}\text { Yield Strength } \\
(\mathrm{N} / \mathrm{mm} 2)\end{array}$ & $\begin{array}{l}\text { Tensile Strength } \\
\text { (N/mm2) }\end{array}$ & $\begin{array}{c}\text { Elongation } \\
(\%)\end{array}$ & $\begin{array}{c}\text { Yield Ratio } \\
(\%)\end{array}$ \\
\hline 30 & Transverse & Full & 388 & 546 & 25.9 & 71 \\
\hline
\end{tabular}

The yield strength of the $30 \mathrm{~mm}$ thick plate, regulated by the industry standard for seismic design ranges from 325 to $445 \mathrm{MPa}$ and that of the $70 \mathrm{~mm}$ thick plate ranges from 295 to $415 \mathrm{MPa}$. The tensile strength has to be between 490 and $610 \mathrm{MPa}$ at all thicknesses. The yield ratio needs to be less than 0.8 and the elongation needs to be more than $21 \%$ for $30 \mathrm{~mm}$ thickness and $23 \%$ for $70 \mathrm{~mm}$ thickness. The base metal used in this study satisfies all these requirements [3].

The tensile test results for the welded joints are listed in Table 6 . For the welded joint in the $30 \mathrm{~mm}$ thick plate, the average tensile strength was $547 \mathrm{MPa}$, which is close to the tensile strength of the base material. For the welded joint in the $70 \mathrm{~mm}$ thick plate, the average tensile strength was $560 \mathrm{MPa}$, which is higher than the tensile strength of the base material. During the tensile tests of the welded joint, the fracture occurred in the HAZ of the base metal, not in the weld metal. This was because the weld joint was designed to be over-matched.

Table 6. Tensile test results of the welded joints. HAZ-heat affected zone.

\begin{tabular}{|c|c|c|c|c|c|c|}
\hline \multirow{2}{*}{$\begin{array}{l}\text { Thickness } \\
\text { (mm) }\end{array}$} & \multirow{2}{*}{ Process } & \multirow{2}{*}{ Position } & \multirow{2}{*}{$\begin{array}{l}\text { Specimen } \\
\text { Type }\end{array}$} & \multicolumn{2}{|c|}{ Tensile Strength $\left(\mathrm{N} / \mathrm{mm}^{2}\right)$} & \multirow{2}{*}{$\begin{array}{l}\text { Location of } \\
\text { the Fracture }\end{array}$} \\
\hline & & & & Specimen 1 & Specimen 2 & \\
\hline 30 & FCAW & Full & Flat & 546 & 547 & $\begin{array}{l}\text { HAZ of the } \\
\text { base metal }\end{array}$ \\
\hline 70 & SAW & $t / 4$ & Round & 559 & 560 & $\begin{array}{l}\text { HAZ of the } \\
\text { base metal }\end{array}$ \\
\hline
\end{tabular}

The guided bend test results of the welded butt joints are listed in Table 7 . No cracks or defects were found on the root and face parts of the weldment.

Table 7. Guided bend test results of the welded butt joints.

\begin{tabular}{cccc}
\hline Thickness $(\mathbf{m m})$ & Process & Specimen No. & Discontinuity Length $(\mathbf{m m})$ \\
\hline \multirow{3}{*}{30} & & 1 (Face) & No defect \\
& FCAW & 2 (Face) & No defect \\
& & 1 (Root) & No defect \\
& 2 (Root) & No defect \\
\hline \multirow{3}{*}{70} & \multirow{3}{*}{ SAW } & 1 (Face) & No defect \\
& & 2 (Face) & No defect \\
& & (Root) & No defect \\
& & (Root) & No defect \\
\hline
\end{tabular}


Regarding the base metal, SN 490C, the Vickers hardness was measured at intervals of $3 \mathrm{~mm}$ in the thickness direction, and the result was 144-168 HV. Regarding butt-joint welds, as shown in Figure 7, the Vickers hardness was measured at $1 \mathrm{~mm}$ intervals from the weld to the base metal based on the fusion line. For the welded joint in the $30 \mathrm{~mm}$ thick plate, the Vickers hardness was 160-220 HV as shown in Figure 7a. The hardness of the face area was slightly higher than that of the root area because the accumulated heat by multi-pass welding transformed the microstructure near the root area. For the welded joint in the $70 \mathrm{~mm}$ thick plate, the Vickers hardness was 164-214 HV as shown in Figure $7 \mathrm{~b}$. The minimum hardness was also measured on the base material, and the maximum hardness was measured on the HAZ. As mentioned in Section 3.1, the formation of rapidly cooled microstructures such as upper bainite and MA in the CGHAZ caused this result.

(a)
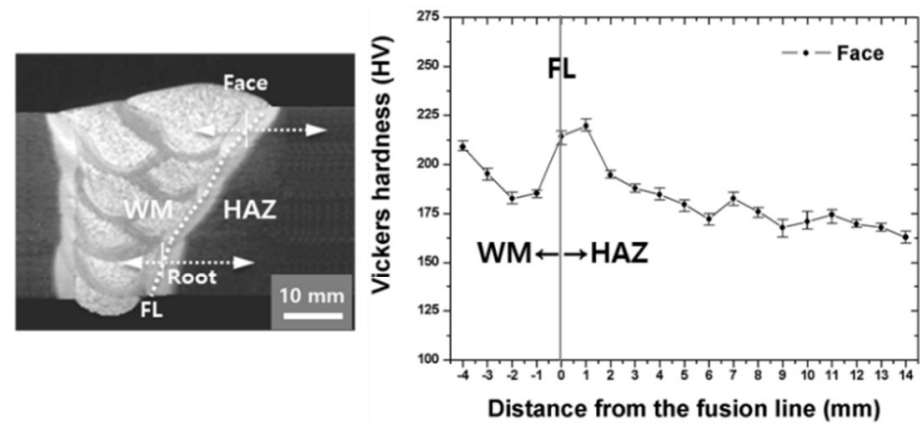

(c)
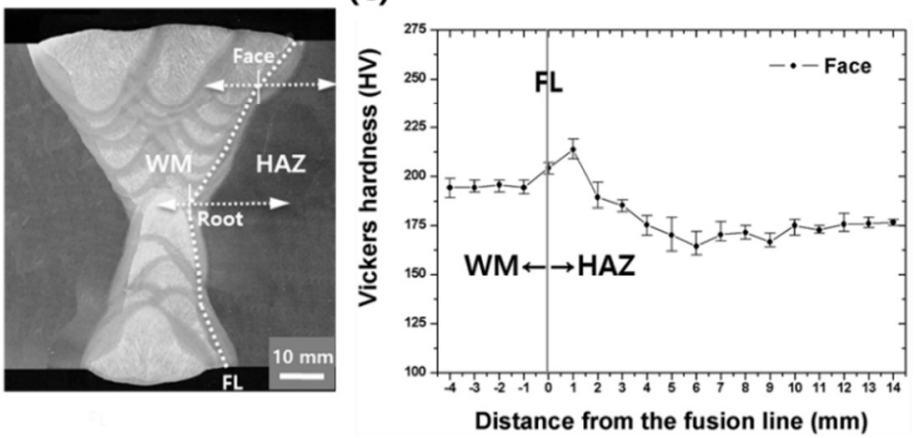

(b)

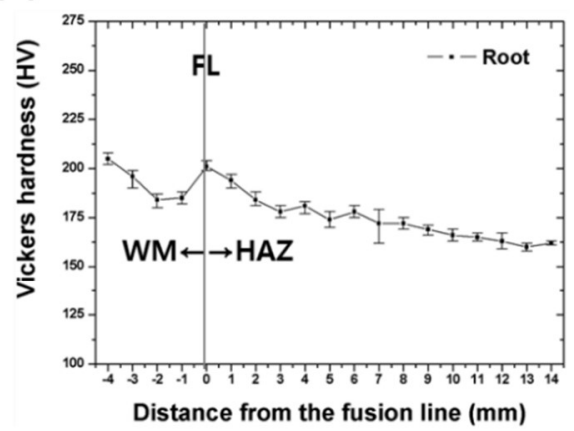

(d)

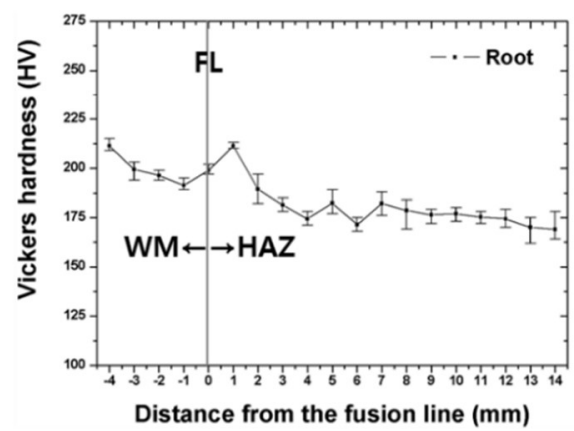

Figure 7. Hardness test results: The butt-joint manufactured by FCAW with the $30 \mathrm{~mm}$ thick plate, (a) face; (b) root. The butt-joint manufactured by SAW with the $70 \mathrm{~mm}$ thick plate, (c) face; (d) root.

As shown in Table 8, the Charpy V-notch impact test depending on the thickness and positions of the SN 490C plates was conducted at $0{ }^{\circ} \mathrm{C}$ to evaluate the toughness of the weldment. The specimen was sampled at the $t / 4$ position of the base metal with lateral direction. The Charpy absorbed energy was $207 \mathrm{~J}$ for the $30 \mathrm{~mm}$ thick sample and $188 \mathrm{~J}$ for the $70 \mathrm{~mm}$ thick sample.

Table 8. Charpy V-notch impact test results depending on the thickness and positions of the SN 490C plates.

\begin{tabular}{ccccc}
\hline Thickness $(\mathbf{m m})$ & Direction & Position & Test Temperature & Average (J) \\
\hline 30 & Lateral & $t / 4$ & $0{ }^{\circ} \mathrm{C}$ & 207 \\
\hline 70 & Lateral & $t / 4$ & $0{ }^{\circ} \mathrm{C}$ & 188 \\
\hline
\end{tabular}

The results of the Charpy impact test in the butt joint welds are depicted in Figure 8. For the absorbed energy in the $30 \mathrm{~mm}$ thick plate welded by FCAW, Figure 8a shows that the Charpy absorbed energy varied from 37 to $164 \mathrm{~J}$ depending on the distance from the fusion line. For the absorbed energy 
in the $70 \mathrm{~mm}$ thick plate welded by SAW, it is shown that the Charpy absorbed energy varied from 177 to $235 \mathrm{~J}$ depending on the distance from the fusion line. Specifically, in the WM and FL of Figure 8a, the energy was low (below $100 \mathrm{~J}$ ), compared with the zone between 2 and $4 \mathrm{~mm}$ away from the FL. However, the corresponding location in Figure $8 \mathrm{~b}$ shows higher energy. This is related with the higher wt. $\%$ of Mn in the SAW filler wire than that in the FCAW filler wire as shown in Table 3. The higher Mn increases the amount of acicular ferrite which increase toughness as shown in Figures 5 and 6 [31,37]. Additionally, the energy abruptly changed between FL $+1 \mathrm{~mm}$ and FL $+2 \mathrm{~mm}$ of Figure $8 \mathrm{a}$. This was because of upper bainite and MA produced in the CGHAZ [38]. It is consistent with the results that the toughness of the CGHAZ is lower than that of other areas $[39,40]$. The Charpy absorbed energy of all specimens showed higher value than the minimum limit of absorbed energy, $27 \mathrm{~J}$, suggested by the industrial standard [3].

(a)

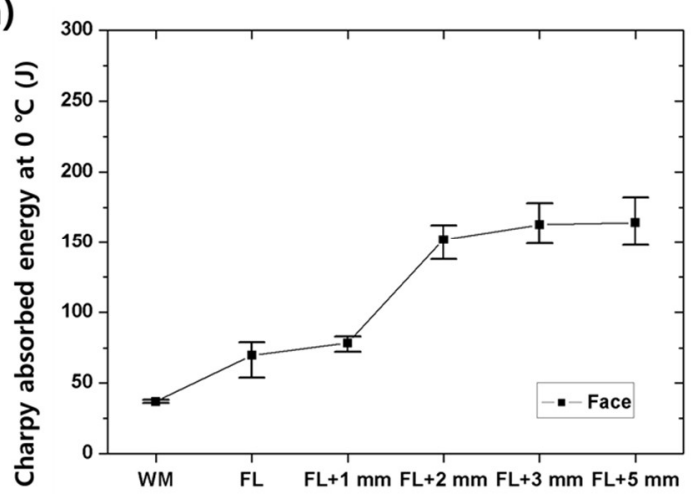

(b)

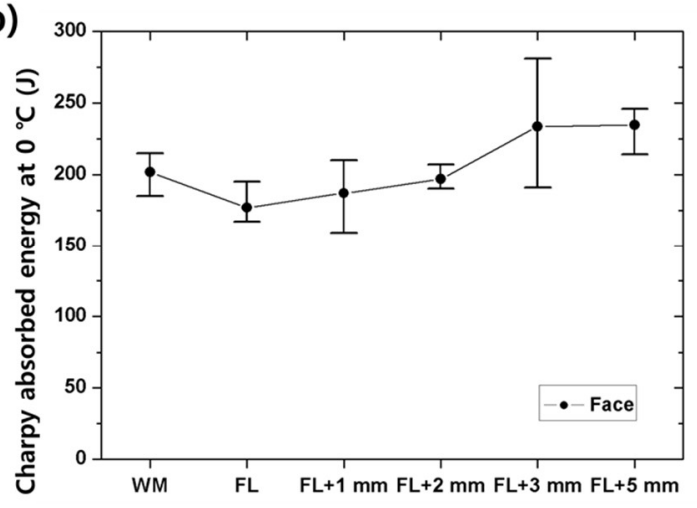

Figure 8. Charpy impact test results: (a) The face area of the butt joint with the $30 \mathrm{~mm}$ thick plate welded by FCAW; (b) the face area of the butt joint with the $70 \mathrm{~mm}$ thick plate welded by SAW.

On the other hand, there were positions in the HAZ where the absorption energy was higher than those of the base metal and the weld metal. This is related with a finer grain size in the FGHAZ by multi-pass welding as shown in Figures 5 and 6. Based on Figures 5 and 6, the FGHAZ appears 2 and $4 \mathrm{~mm}$ away from the fusion line, respectively. This tendency is similar to the toughness results. It is also consistent with a research result that toughness is improved as grain is refined in the HAZ [41].

Figure 9a shows the macro-examination results of the T-joint manufactured by the FCAW process in the $2 \mathrm{G}$ position as shown in Figure 2a. Figure $9 \mathrm{~b}$ enlarges the bottom of the bead shown in Figure 9a. The welded parts consist of multi-layer welding. No cracks or defects were found by macro-observation.

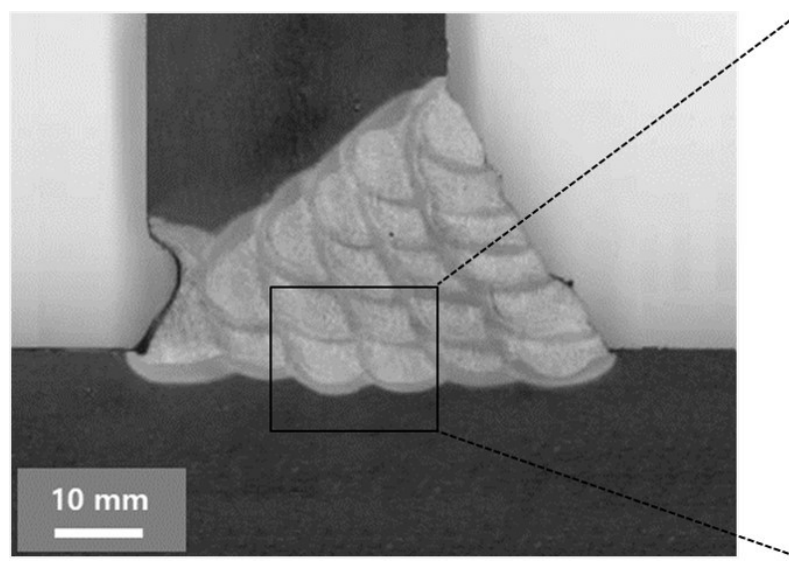

(a)

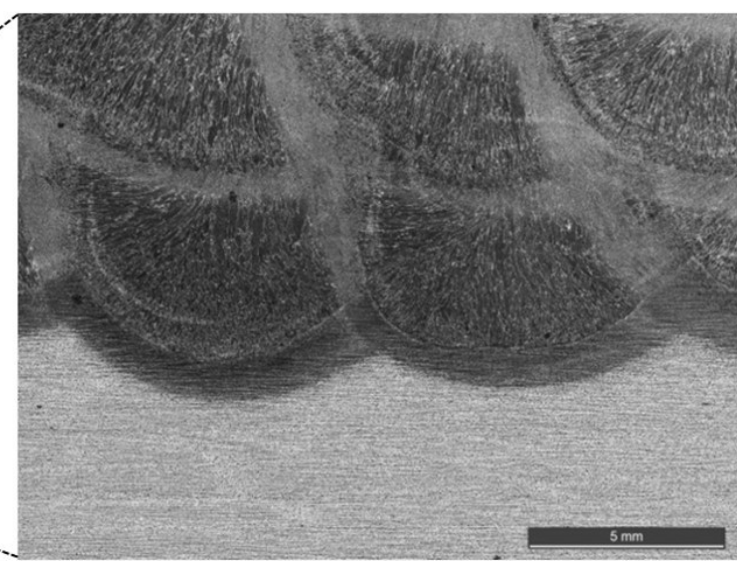

(b)

Figure 9. (a) Macrography of the welded T-joint of the $30 \mathrm{~mm}$ thick plate, and (b) inset-magnification around the fusion line of the welded T-joint. 
Figure 10 shows the hardness measurement profile on the weldment shown in Figure 9. The ' $h$ ' in Figure 10 is the distance from the outer face of the weldment to the point where the hardness is measured. The hardness of the HAZ was higher than that of the base material or weld metal. As shown in Figure 10, the maximum hardness is $326 \mathrm{HV}$ in the HAZ of the rightmost weld toe. Even though the heat input of this T-joint weld was the same as that of the butt join weld, as explained in the previous section, the peak hardness has a considerable difference. This was caused by the changes between the cooling rate which was induced by welding position $1 \mathrm{G}$ and $2 \mathrm{G}$, respectively.

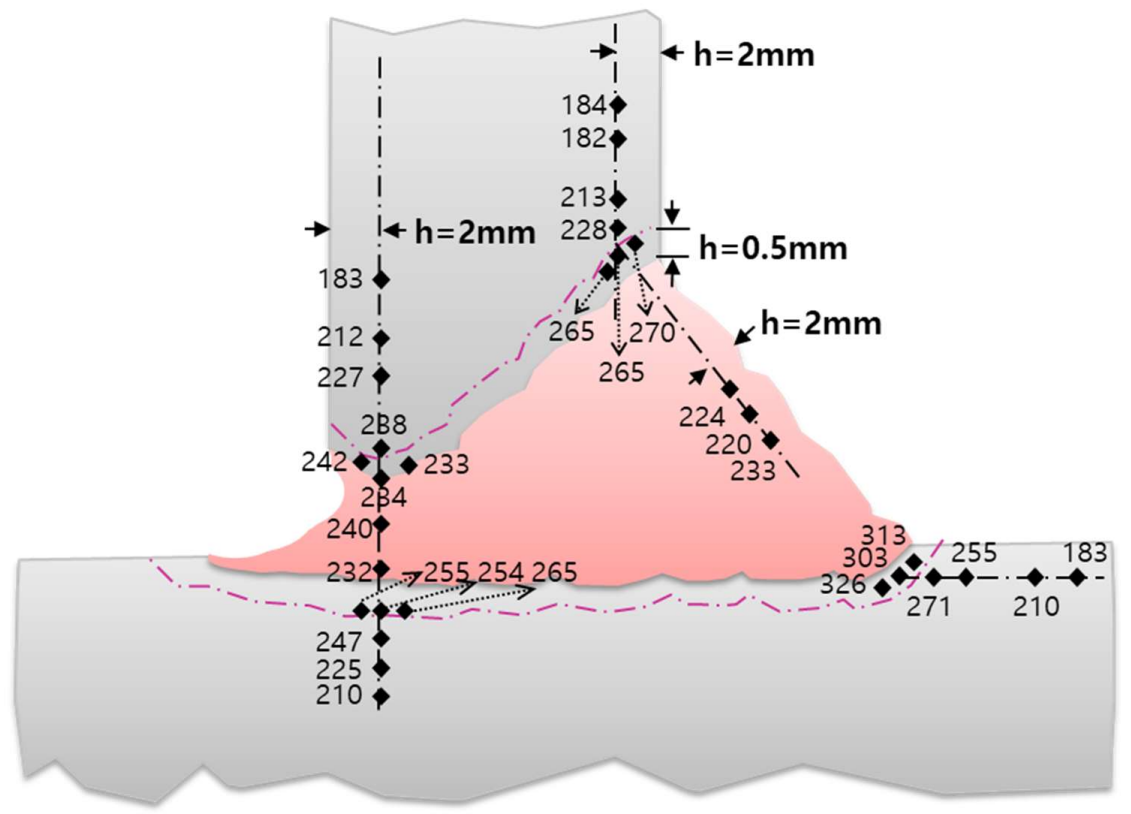

Figure 10. Hardness distribution of the welded T-joint with the $30 \mathrm{~mm}$ thick plate preheated up to 50 ${ }^{\circ} \mathrm{C}$.

Figure 11 shows the macro-examination results of the weldment produced by a single-pass FCAW process. The double-fillet T-joint configuration using the $30 \mathrm{~mm}$ thick plate was shown in Figure $2 \mathrm{~b}$. The A side and B side were preheated up to 150 and $50{ }^{\circ} \mathrm{C}$, respectively, since these operating conditions are used in the actual field of building structures for preventing defects. No cracks or defects were found by macro-examination. Hardness was measured on the points where the numbers are marked in Figure 11. Table 9 shows the result of the hardness distribution of the double-fillet T-joint welded in the FCAW process. The base material had a hardness from 153 to $156 \mathrm{HV}$ on both sides. The weld metal had a hardness from 243 to $261 \mathrm{HV}$. The hardness in all the HAZs varied from 283 to $340 \mathrm{HV}$.

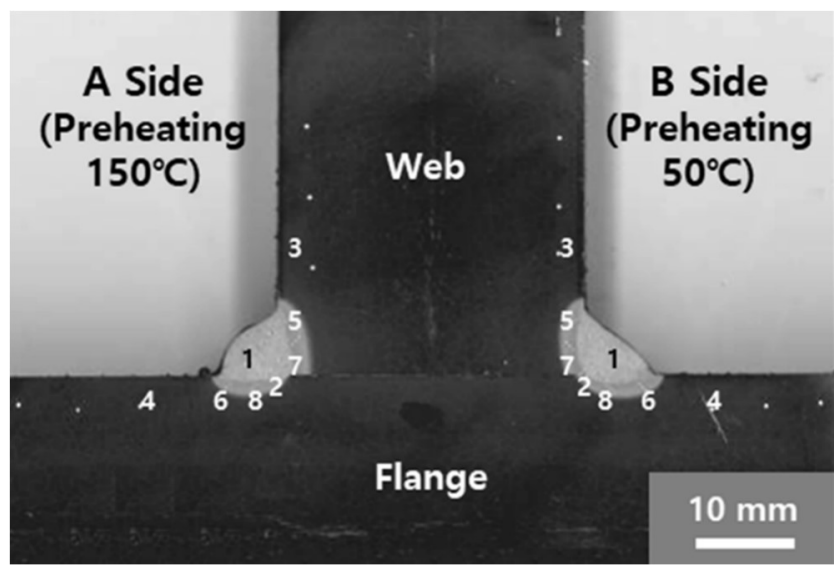

Figure 11. Hardness measurement positions of the welded double-fillet T-joint of the $30 \mathrm{~mm}$ thick plate. 
Table 9. Hardness distribution of the double-fillet T-joint welded in FCAW process. WM-weld metal, BM-base metal.

\begin{tabular}{ccc}
\hline Position & A Side (HV, Preheating: $\left.\mathbf{1 5 0}{ }^{\circ} \mathbf{C}\right)$ & B Side (HV, Preheating: $\left.\mathbf{5 0}{ }^{\circ} \mathbf{C}\right)$ \\
\hline 1. WM (Face) & 254 & 261 \\
2. WM (Root) & 250 & 243 \\
3. BM (Web) & 156 & 156 \\
4. BM (Flange) & 153 & 156 \\
5. HAZ Face (Web) & 302 & 331 \\
6. HAZ Face (Flange) & 283 & 306 \\
7. HAZ Root (Web) & 313 & 324 \\
8. HAZ Root (Flange) & 318 & 340 \\
\hline
\end{tabular}

The welds preheated to $150{ }^{\circ} \mathrm{C}$ generally showed lower hardness than the welds preheated to $50{ }^{\circ} \mathrm{C}$. This is because of the difference in cooling rate of the welds depending on the preheating temperature. On both sides, the hardness in the HAZ of the flange root was the highest. In addition, higher hardness values were obtained with single-pass welding than with multi-pass welding. This is due to rapid cooling by the web and the flange plate during the single-pass welding.

Consequently, as shown in Figure 10 and Table 9, the full-penetration butt T-joints and the partial-penetration fillet T-joints showed the highest hardness values in the HAZ. The results of these hardness tests show the same tendency with the various studies that conducted hardness tests on the weldment [42].

\subsection{Lamellar Tearing Susceptibility}

A through-thickness tensile test was performed to evaluate the lamellar tearing susceptibility. Consequently, the reduction in cross-sectional area was calculated as $51 \%$ for the $30 \mathrm{~mm}$ thick plate, SN $490 \mathrm{C}$. For the plate of $70 \mathrm{~mm}$ thickness, the reduction in the area was calculated as $61 \%$. It was reported that the lower reduction of area indicates the higher chance of cracking [43]. In both cases, the test results were above $25 \%$, which is the limit by the industrial standard [3].

As seen in Figure 12, two full-penetrated weldments were manufactured to perform a window test. The weldments were produced by multi-layer welds. Figure $12 \mathrm{a}, \mathrm{b}$ represents the weldments manufactured by the FCAW process depending on the thickness of 30 and $70 \mathrm{~mm}$, respectively. There was no cracks or lamellar tearing in each case.
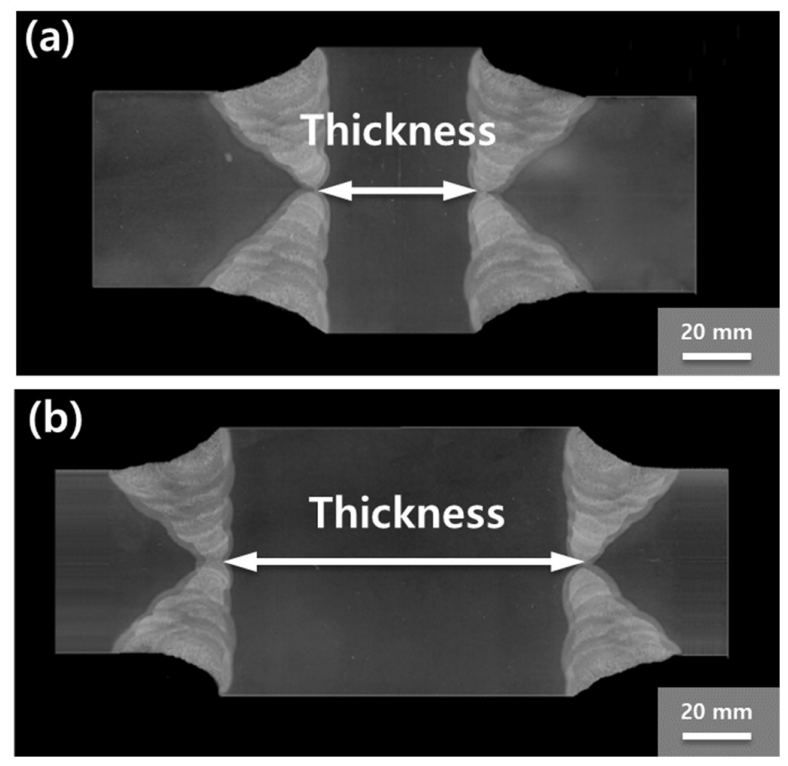

Figure 12. Window test results: (a) the $30 \mathrm{~mm}$ thick plate; (b) the $70 \mathrm{~mm}$ thick plate. 
Moreover, as shown in Figure 13, two partial-penetrated weldments were manufactured to perform the Cranfield test. The weldments were produced by multi-layer welds. Figure 13a,b represents the weldments manufactured by the FCAW process depending on the thickness of 30 and $70 \mathrm{~mm}$, respectively. Consequently, there was no cracks or lamellar tearing in each thickness.
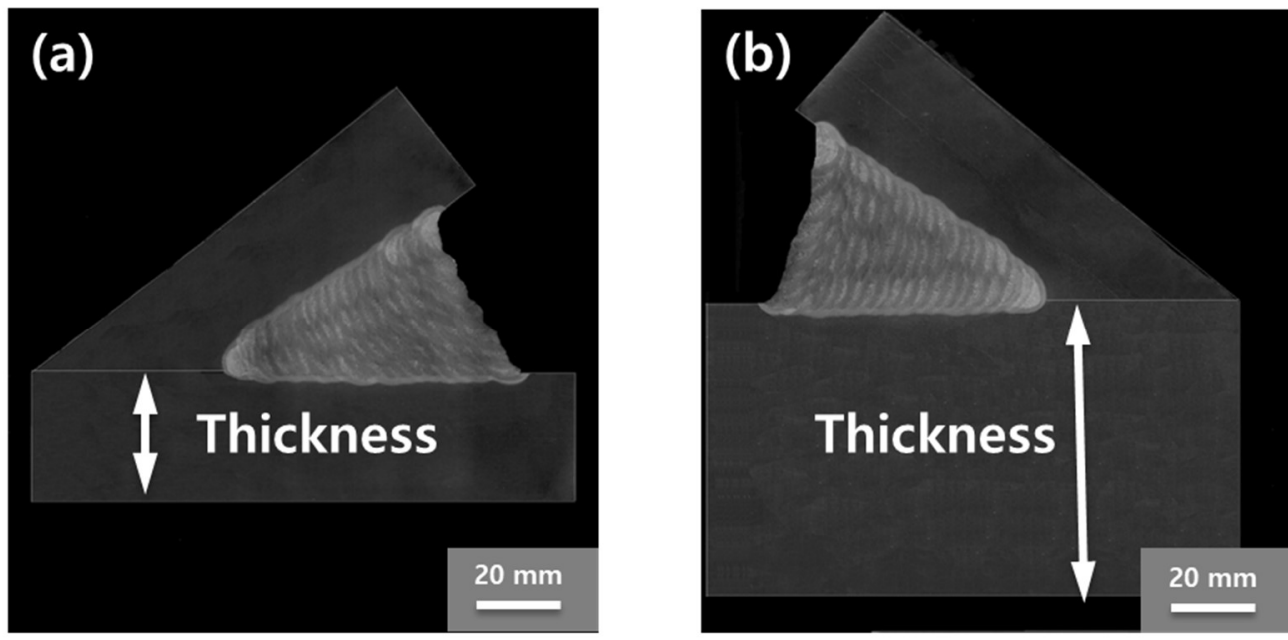

Figure 13. Cranfield test results: (a) the $30 \mathrm{~mm}$ thick plate; (b) the $70 \mathrm{~mm}$ thick plate.

\section{Conclusions}

In this study, the weldability and cracking susceptibility of welded SN 490C which had been developed for anti-seismic steel of building structures were firstly investigated. The weldments of SN 490C steel were manufactured by FCAW and SAW processes. Various tests were conducted to evaluate the weldability and lamellar tearing susceptibility of the SN 490C steels. The conclusions from the various tests are summarized as follows.

1) SN 490C has the characteristics of typical carbon steel and satisfies the industrial standard in terms of the chemical composition, yield strength, tensile strength, yield ratio, elongation, and Charpy absorbed energy. This was confirmed through chemical composition analysis, tensile test, impact toughness test, and microstructure analysis on the SN 490C.

2) The weldability of SN 490C steel was evaluated by the tensile test, impact toughness test, hardness test, and microstructure analysis. For the tests, the butt-joint weldments were produced by FCAW and SAW processes depending on thickness. The weldability in T-joints was also evaluated. The samples of the various types of T-joints, which are often used in the manufacturing field to build steel structures, were produced by the FCAW process.

3) In the hardness test of the weldment, the reason that the HAZ shows higher hardness than the base metal or the weld metal is the formation of the upper bainite microstructure in the CGHAZ. The packet size of the upper bainite become smaller toward the FGHAZ from the fusion line. This was correlated with the toughness test results. Additionally, the wt.\% of Mn in the different filler wires was found to be the cause for different Charpy impact absorbed energies in the weld metal. Specifically, the Mn content related with the formation of the acicular ferrite causes the increase of the hardness in the weldment.

4) Three kinds of tests were carried out. The through-thickness tension of the base material showed satisfactory reduction in sectional area. The window and Cranfield tests were performed on weldments with thicknesses of 30 and $70 \mathrm{~mm}$. The macro-examination result of the weldment showed no cracks or lamellar tearing in each thickness.

Author Contributions: D.V. and S.H.L. conceived and designed the study. D.V., K.K. and H.S. performed the experiment. D.V. and S.H.L. drafted this paper. 
Funding: This research received no external funding.

Conflicts of Interest: The authors declare no conflict of interest.

\section{References}

1. Horikawa, K.; Sakino, Y. Review of damage in welded joints caused by the Kobe earthquake. Trans. JWRI. 1995, 24, 1-10.

2. Shi, G.; Ban, H.-Y.; Shi, Y.; Wang, Y. Overview of research progress for high strength steel structures. Eng. Mech. 2013, 30, 1-13.

3. Rolled steels for building structure, JIS G 3136; Japanese Standards Association: Tokyo, Japan, 2012. (In Japanese)

4. Rolled steel for building structures, KS D 3861; Korean Agency for Technology and Standards: Chungcheongbuk-do, Korea, 1999. (In Korean)

5. Korean Building Code 2016; Structural Korean Ministry of Land, Infrastructure and Transportation: Sejong-si, Korea, 2016. (In Korean).

6. Kim, K.H.; Moon, I.J.; Kim, K.W.; Kang, K.B.; Park, B.G.; Lee, K.S. Influence of Carbon Equivalent Value on the Weld Bead Bending Properties of High-Strength Low-Alloy Steel Plates. J. Mater. Sci. Technol. 2017, 33, 321-329. [CrossRef]

7. Bjorhovde, R. Development and use of high performance steel. J. Constr. Steel. Res. 2004, 60, 393-400. [CrossRef]

8. Jiang, J.; Zhang, J.; Liu, J.; Chiew, S.P.; Lee, C.K. Effect of welding and heat treatment on strength of high-strength steel columns. J. Constr. Steel. Res. 2018, 151, 238-252. [CrossRef]

9. Kim, S.J.; Jeong, H.C. Development of Structural Steel and Trend of Welding Technology. Sci. Technol. Weld. Joi. 2016, 34, 7-20. [CrossRef]

10. Jeong, H.C.; Lee, J.-W. Recent Development of Structural Steel and Its Weldability for Construction. Sci. Technol. Weld. Joi. 2009, 27, 49-58.

11. Kaneko, H. Influence of strain-rate on yield ratio. Kobe Earthquake Damage to Steel Moment Connections and Suggested Improvement; JSSC Technical Report: Chuo, Japan, 1997.

12. Yurioka, N. Impact of welding research on steel composition development. Mater. Des. 1985, 6, $154-171$. [CrossRef]

13. Ito, Y.; Bessyo, K. Weldability formula of high strength steels related to heat affected zone cracking; Sumitomo Search: Tokyo, Japan, 1968; Volume 37.

14. Farrar, J.; Dolby, R. Lamellar Tearing in Welded Steel Fabrication; TWI Ltd.: Cambridge, UK, 2001.

15. Qiu, H.; Mori, H.; Enoki, M.; Kishi, T. Effect of welding thermal cycle and cold working on the ductility of SN490 steel under low and high-speed loading. Mater. Sci. Eng. A 2001, 316, 217-223. [CrossRef]

16. ASTM A770/A770M-03, Standard Specification for Through-Thickness Tension Testing of Steel Plates for Special Applications; ASTM International: West Conshohocken, PA, USA, 2003.

17. Farrar, J.C.M.; Dolby, R.E. An Investigation into Lamellar Tearing. Met. Const. 1969, 1, 32-39.

18. Jubb, J. Lamellar Tearing; W.R.C: Shaker Heights, OH, USA, 1971; Volume 168.

19. Sakino, Y.; Horikawa, K.; Kamura, H. Welding Heat Input Limit of Rolled Steels for Building Structures Based on Simulated HAZ Tests (Mechanics, Strength \& Structure Design). Trans. JWRI 2001, 30, 127-134.

20. Sakino, Y.; Kim, Y.-C. Comparison of Charpy absorbed energy of heat affected zones in low and high toughness steel. Int. J. Steel. Struct. 2013, 13, 21-29. [CrossRef]

21. Furuya, H.; Uemori, R.; Aihara, S.; Nagata, M.; Ikebe, T.; Kojima, T.; Murakami, Y.; Okamoto, H.; Kudo, J.; Kubo, T.; et al. Newly Proposed HAZ Toughness Evaluation Method of Structural Steel for Building and the Result of Evaluation by Its Application. Kou kouzou Rombunshuu 2000, 7, 23-37. [CrossRef]

22. Hasebe, S.; Bessyo, K.; Nito, N.; Asai, Y.; Nakamura, M. Lamellar Tearing and Through-Thickness Properties of Steel Plate; Sumitomo Search: Tokyo, Japan, 1974; pp. 25-38.

23. Miura, N. Evaluation of tensile properties of safety-conscious rolled steels for building structure (SN steels) at high temperature Expansion of tensile property data at higher temperature. Denryoku Chuo Kenkyusho Hokoku 2014, 46, 1-27.

24. Tenderan, R.; Ishida, T.; Jiao, Y.; Yamada, S. Seismic Performance of Ductile Steel Moment-Resisting Frames Subjected to Multiple Strong Ground Motions. Earthq. Spectra. 2019, 35, 289-310. [CrossRef] 
25. Kayamori, Y.; Kawabata, T.; Hagihara, Y. Formulation of CTOD design curve considering the yield to tensile ratio. Procedia Struct. Integrity 2017, 5, 279-285. [CrossRef]

26. Choi, I.-R.; Chung, K.-S.; Lee, H. Thermal and mechanical properties of structural steel SN400 at elevated temperatures. Int. J. Steel. Struct. 2017, 17, 999-1007. [CrossRef]

27. AWS-A5.20/A5.20M:R2015 Carbon Steel Electronics for Flux Cored Arc Welding; AWS: Miami, FL, USA, 2015.

28. AWS-A5.17/A5.17M-97 (R2007) Specification for Carbon Steel Electrodes and Fluxes for Submerged Arc Welding; AWS: Miami, FL, USA, 2007.

29. ASTM E3-11(2017), Standard Guide for Preparation of Metallographic Specimens; ASTM International: West Conshohocken, PA, 2017.

30. Babu, S.S. The mechanism of acicular ferrite in weld deposits. Curr. Opin. Solid. State. Mater. Sci. 2004, 8, 267-278. [CrossRef]

31. Koseki, T.; Thewlis, G. Overview Inclusion assisted microstructure control in C-Mn and low alloy steel welds. Mater. Sci. Tech. 2005, 21, 867-879. [CrossRef]

32. Cao, R.; Li, J.; Liu, D.S.; Ma, J.Y.; Chen, J.H. Micromechanism of Decrease of Impact Toughness in Coarse-Grain Heat-Affected Zone of HSLA Steel with Increasing Welding Heat Input. Metall. Mater. Trans. A Phys. Metall. Mater. Sci. 2015, 46, 2999-3014. [CrossRef]

33. Abdelkader, G.; Abdelbaki, N.; Gaceb, M.; Mourad, B. Effects of Martensite-Austenite Constituents on Mechanical Properties of Heat Affected Zone in High Strength Pipeline Steels-Review. Chem. Eng. Trans. 2018, 70, 583-588. [CrossRef]

34. Li, X.; Ma, X.; Subramanian, S.; Shang, C.; Misra, R. Influence of prior austenite grain size on martensite-austenite constituent and toughness in the heat affected zone of $700 \mathrm{MPa}$ high strength linepipe steel. Mater. Sci. Eng. A 2014, 616, 141-147. [CrossRef]

35. Matsuda, F.; Ikeuchi, K.; Fukada, Y.; Horii, Y.; Okada, H.; Shiwaku, T.; Shiga, C. Review of Mechanical and Metallurgical Investigations of M-A Constituent in Welded Joint in Japan. Trans. JWRI 1996, 3, 134-154.

36. Ma, R.; Fang, K.; Yang, J.; Liu, X.; Fang, H. Grain refinement of HAZ in multi-pass welding. J. Mater. Process. Technol. 2014, 214, 1131-1135. [CrossRef]

37. Evans, G. The Effect of Heat Input on the Microstructure and Properties of C-Mn All-Weld-Metal Deposits. Weld. J. 1982, 61, 125.

38. Luo, X.; Chen, X.; Wang, T.; Pan, S.; Wang, Z. Effect of morphologies of martensite-austenite constituents on impact toughness in intercritically reheated coarse-grained heat-affected zone of HSLA steel. Mater. Sci. Eng. A 2018, 710, 192-199. [CrossRef]

39. Lan, L.; Qiu, C.; Zhao, D.; Gao, X.; Du, L. Analysis of microstructural variation and mechanical behaviors in submerged arc welded joint of high strength low carbon bainitic steel. Mater. Sci. Eng. A 2012, 558, 592-601. [CrossRef]

40. Huda, N.; Midawi, A.R.H.; Gianetto, J.; Lazor, R.; Gerlich, A.P. Influence of martensite-austenite (MA) on impact toughness of X80 line pipe steels. Mater. Sci. Eng. A 2016, 662, 481-491. [CrossRef]

41. Kojima, A.; Yoshii, K.-i.; Hada, T.; Saeki, O.; Ichikawa, K.; Yoshida, Y.; Shimura, Y.; Azuma, K. Development of High HAZ Toughness Steel Plates for Box Columns with High Heat Input Welding; Shinnittetsu Giho: Tokyo, Japan, 2004; pp. 33-37.

42. Eroğlu, M.; Aksoy, M.; Orhan, N. Effect of Coarse Initial Grain Size on Microstructure and Mechanical Properties of Weld Metal and HAZ of a Low Carbon Steel. Mater. Sci. Eng. A 1999, 269, 59-66. [CrossRef]

43. Kanazawa, S.; Kawamura, K.; Yamato, K.; Haze, T.; Inoue, T.; Nuibe, T.; Fukudu, T. Lamellar tear resisting steels. The directions for use of them; I.I.W.: Villepinte, France, 1974; Volume 74.

(C) 2019 by the authors. Licensee MDPI, Basel, Switzerland. This article is an open access article distributed under the terms and conditions of the Creative Commons Attribution (CC BY) license (http://creativecommons.org/licenses/by/4.0/). 